\title{
Comparative Study of the Impact of Oil Rent on Healthcare in Nigeria and Cameroon: A Three Stage Methodical Approach
}

\author{
EWUBARE, Dennis Brown \& OBAYORI, Elizabeth Lizzy \\ Rivers State University, Department of Agricultural and Applied Economics, \\ Faculty of Agriculture, Port Harcourt, Nigeria
}

\begin{abstract}
The study comparatively examined the impact of oil rent on healthcare in Nigeria and Cameroon from 1995 to 2015. The objectives of the study are to; study the trend of oil rents and healthcare in Nigeria and Cameroon; examine the relationship between oil rent and healthcare of Nigerians and Cameroonians and determine the impact of mineral rent on the healthcare of Nigeria and Cameroon. To achieve these objectives panel data were collected on health, oil rent and mineral rent and analyzed using the econometric techniques of panel unit root test and panel cointegration test as well as graphical method. The panel unit root and cointegration test showed that all the series are indeed stationary and have long run equilibrium relationship. Comparatively, the graph showed that the rents from oil in Nigeria are lower than that of Cameroon. Also, Cameroon performs better in rents from minerals than Nigeria. Thus, Cameroon capital expenditure on health has steadily increased since 1995 up to 2015 while Nigeria seems not to take healthcare expenditure serious hence the dismal performance in the infant mortality rates. Based on the findings, it is recommended that revenue from oil should be towards inclusive growth, thereby impacting significantly on the healthcare and welfare of the citizens. Thus, there should be investment in primary as well as maternal health in the rural areas for the disadvantaged in society.
\end{abstract}

Key Words: Nigeria, Cameroon, Mortality Rate, Oil Rent, Mineral Rent, Health, Cointegration

\subsection{INTRODUCTION}

In most oil producing countries, economic stability today can be gauged using oil as an indicator due mainly to importance ascribed to it via heavy reliance on its derivatives. Being one of the most important commodities in today's industrialized world and one of the major traded good in terms of volume and value, its price is of critical importance and thus has been subject to wide oscillations due to the forces of demand and supply.

In the 1970's the world experienced the first major oil price which triggered investigations into the dicey relationship between the price of oil and the growth of economies of both oil producing and non-oil producing countries. The relationship however depends on the side a country finds itself. Generally, as world economic growth increases, the demand for oil increases which pushes up oil price. For instance, in 2007 a strong world economic growth driving demand in oil use increased price of oil from an average of nearly $\$ 55$ per barrel in the first quarter of 2007 to over $\$ 95$ per barrel in the last quarter of 2007. All things equal, oil price increase in oil exporting countries should be considered positive and negative in oil importing countries and the reverse should be expected when oil price decreases (Boheman\&Maxen, 2015).

Meanwhile, copious scholarships on oil often use the price of oil as their focal variable in analysing different impacts of oil on the economy. But oil rent is basically the difference between the value of crude oil production at world prices and total costs of production. Natural resource rents are the revenues that a country earns from the extraction of a natural resource after making an allowance for the cost of extraction of the resource. Included in this category are oil rents, coal rents, mineral rents, and forest rents. These revenues are called rents since the product is not manufactured or man-made, but extracted. Since their supply is limited, these natural resources command high returns. 
While existing literature focuses on the impact of oil prices on manufacturing, agriculture, public, private, domestic and foreign investments, the stock exchange, the financial sector etc, there seems to be no empirical evidence of its effect on health care. Also, existing literature on oil also rarely explain the relationship that exists between oil and socioeconomic indices such as corruption and health care (Opaleye, Okowa\&Ohale, 2018).

In the meantime, oil sector accounts for a significant amount of revenue in oil producing countries in Africa. The sector over the years has become a major contributor to GDP, economic growth and development, foreign exchange and reserves to these countries in the past decades. In Nigeria for instance, oil contributes $90 \%$ of foreign exchange earnings and 65\% of foreign exchange earnings in Cameroon in 2014. In terms of foreign reserves, Nigeria has reserves of US\$30bn as at $8^{\text {th }}$ March 2017, while Cameroon foreign reserve was US\$2.26bn as at $31^{\text {st }}$ December 2016.But these huge revenues have not been efficiently utilised, in term of development when been compared with countries in Europe and North America (World Bank, 2016).

According to Agnihotri(2015), it is interesting to note that oil producing countries such as Nigeria and Cameroon still receive one form of financial aid or the other from developed countries despite the enormous revenues earned from oil. Despite this, these countries still have difficulty in improving the quality and standards of life for their citizens due to corruption or large scale mismanagement of resources.For instance, Sub Saharan Africa like Nigeria and Cameroon has $24 \%$ of the global burden of disease but only $3 \%$ of the workforce in the health sector. This scenario accounts for consistent outbreak of diseases which results to low life expectancy as well as increase in mortality rate .For instance, infant mortality for kids below 5 years of age in Nigeria and Cameroon as at 2015 stands at 108 and 88 per 1,000 live births compared to 3 in Sweden and 7 in the United States of America (USA) under the same period while life expectancy on the other hand is 53 in Nigeria as at 2015 compared to 83 in Sweden, 79 in USA(Opaleye, Okowa\&Ohale, 2018).It is this worrisome state of affair that geared the study towards examining the impact of oilrenton healthcare in Nigeria and Cameroon.

\subsection{Oil Rent and Health Nexuses}

literature on the relationship between oil and health status include the work of Sachs and Warner (1997) who uses life expectancy as proxy for health, they found an inverted U relationship between health human capital and GDP growth. This implies that enhanced health status for a generally sick society improves economic growth but as the society begins to recover generally, the contribution to growth lessens. In like manner, Schultz (2005) examined the impact of health on total factor productivity and discovered that improved human health capital directly increase workers efficiency and productivity.

Boussalem, Boussalem and Taiba (2014) examine the causality relationship between economic growth and public spending on health in Algeria for a period of 30years and found the existence of a long run connection between health spending and growth in national output. Anyanwu (2007) examined health expenditure and health outcomes in Africa. They found that public health expenditure per capita play very important role in determining health outcomes in Africa. In addition, per capita income was found to be negatively related to less than five mortality in sub-Saharan Africa. HIV and malaria prevalence was found to positively influence health outcomes.

Using panel data for 118 developing countries for the period 1971-2000, Baldacci, Clement, Gupta and Cui (2008) explored the channel that connects social spending, economic growth and human capital. The result showed a significant relationship between economic growth, health and education. Saleh (2016) used impulse response to examine oil revenue and macroeconomic performance in Oman. His analysis showed that government spending in education and health responded to a significant and positive shock in economic performance. Employing vector auto-regression (VAR) method of analysis, IbrahimandOhwofasa (2015) examined the determinants of education expenditure in Nigeria for a period of 33 years and found that oil revenue happens to be the most important factor that determines the level of funding and investment in education in any particular year in the country both in the short and long run. 


\subsection{Methodology}

The data to be employed in this study were mainly panel data for Nigeria and Cameroun. The datawere sourced from the World Bank data archive. The three methods used to analysed the data are; the graphical approach which help to determine the trend and the behaviour of the various variables used. Also, the panel unit root test via ImPesaran-Shin (2003), help to test whether a time series variable is non-stationary and possesses a unit root. While the panel cointegrations test via Pedroni (2001) help to check a long-run equilibrium relationship among the series.

\subsection{Model Specification}

The functional model was formalized in four models as follows:

$\mathrm{HST}=\mathrm{f}(\mathrm{ORET}, \mathrm{MRET})$

Accordingly, the econometric form of the model is stated as:

$\operatorname{HST}_{\mathrm{t}}=\beta_{0}+\beta_{1} \mathrm{ORET}_{\mathrm{t}}+\beta_{2} \mathrm{MRET}_{\mathrm{t}}+\mu_{\mathrm{t}}$

HST $=$ Health (proxy by child mortality under five years of age), ORET $=$ Oil Rent, MRET $=$ Mineral Rent, $\mu_{\mathrm{t}}=$ Error term

\subsection{Empirical Data Analysis}

\subsection{Trend Analysis}

The figures below, graphically illustrate the trends of the variables for the two countries.

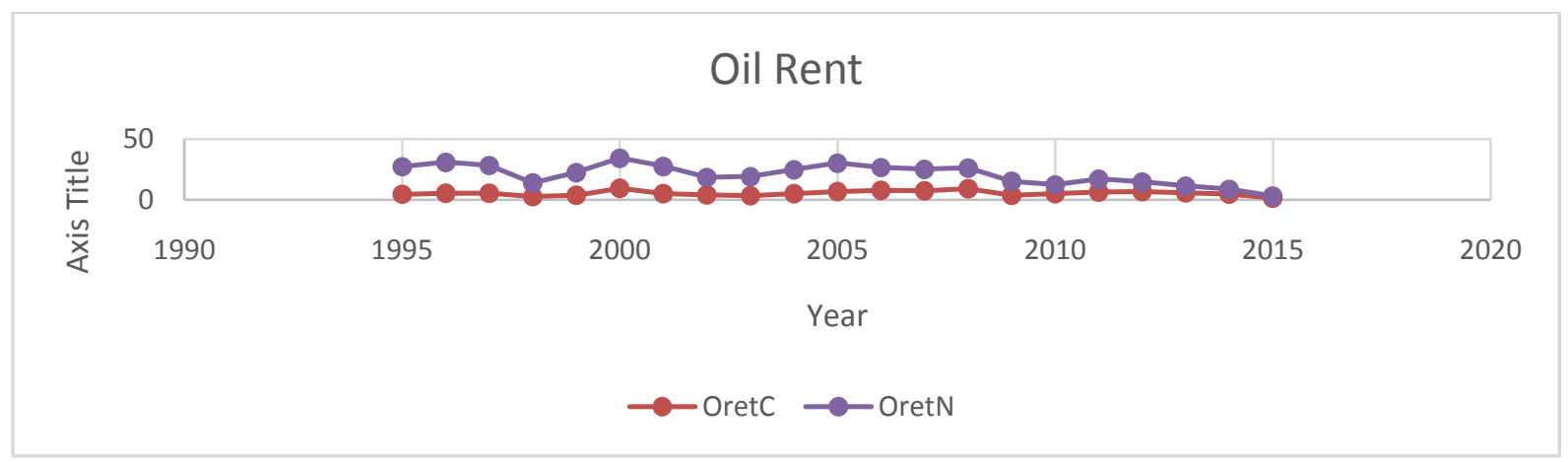

Source: Authors' Computation (2019)

\section{Figure 1: Trend Analysis of Oil Rent}

From the figure above, in 1995 oil rent in Nigeria (OretN) was higher than that of Cameroon (OretC). But in the year 1998, oil rent slumped due to slow down in the world economy which affected the oil producing countries. But the year 2000 accounts for the peak period of Nigerian and Cameroon oil rent. In 2008, oil rent in Nigeria and Cameroon were falling; however, the rate of falling of Nigeria oil rent was higher than that of the Cameroon. In summary, the graph showed that the rents from oil in Nigeria fall faster than that of Cameroon. 


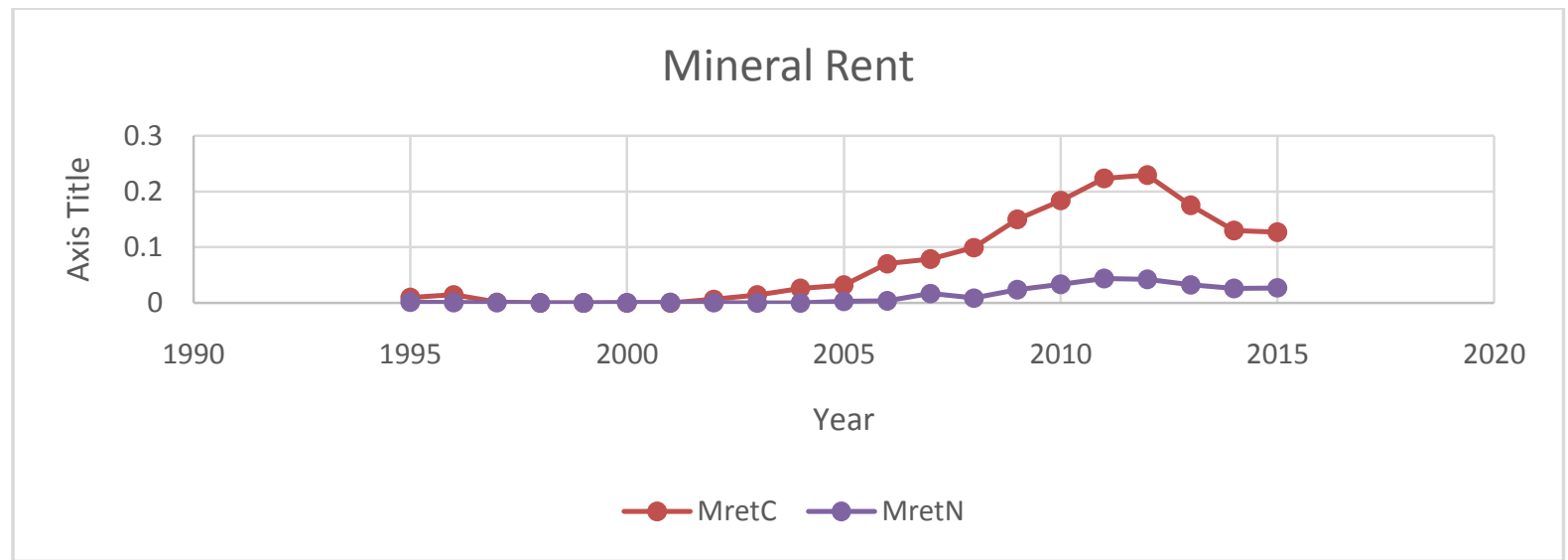

Source: Authors' Computation (2019)

\section{Figure 2: Trend Analysis of Mineral Rent}

The graph above showed that between 1995-2005 rent from minerals which serves as a check variable in the estimated model were virtually minute. But after the year 2005, mineral rent in Cameroon (MretN)grew but not significantly. While that of Nigeria mineral rent (MretN) is still very low. In 2012 however, Cameroon witnessed the peak rent levels from minerals though this began to fall in 2013.Generally it can be concluded that Cameroon performs better in rents from minerals than Nigeria.

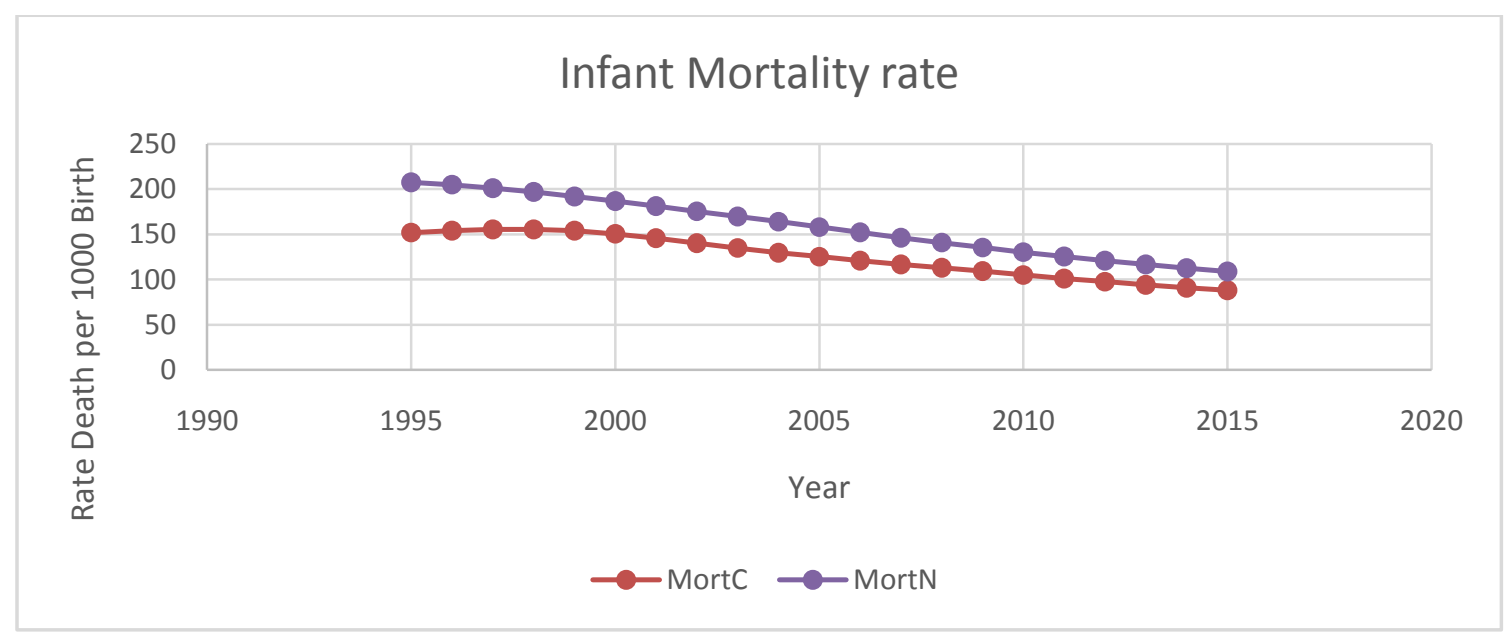

Source:Authors' Computation (2019)

Figure 3: Trend Analysis of Child Mortality under the Age of Five (Proxy for Health Status)

From the figure above, Nigeria (MortN) and Cameroun (MortC) had very high infant mortality in 1995. But Nigeria infant mortality rate is higher compared to that of Cameroon. Despite gradual reduction in mortality rate, Nigeria still experiences more than a hundred infant deaths per year. This Implies that, Nigeria does not fared better than Cameroon in term of infant mortality rate. The trend above clearly explains that in Cameroon, capital expenditure on health have steadily been increasing since 1995 up to 2015 while Nigeria seem not to be show serious concern to health expenditure which led to increase in mortality rates. 


\subsection{Analysis of Empirical Result}

Table 1: Stationarity Test Using Im, Pesaran\& Shin Test (IPS)

\begin{tabular}{lcc|cc}
\hline \multicolumn{1}{c|}{ Variables } & \multicolumn{2}{c}{ Level 1(0) } & \multicolumn{2}{c}{ First order difference I(1) } \\
\hline \multirow{2}{*}{ Constant } & Status & \multicolumn{2}{c}{ Constant } & Status \\
\cline { 2 - 4 } Status & -0.6560 & Not Stationary & $-1.9794^{*}$ & Stationary I(1) \\
& $(0.2559)$ & & $(0.0239)$ & \\
Oil Rent & 1.7393 & Not Stationary & $-5.5569 *$ & Stationary I(1) \\
& $(0.9590)$ & & $(0.0000)$ & \\
Mineral Rent & 0.3695 & Not Stationary & $-8.8752 *$ & Stationary I $(1)$ \\
& $(0.6441)$ & & $(0.0000)$ & \\
\hline
\end{tabular}

Note:*, ** indicates rejection of the null hypothesis of no stationarity at $5 \%$, levels of significance.

Sources: Researcher's Computation Based on E-view 10.

The Im, Pesaran and Shin(IPS) panel unit root test result presented in Table 1 showed that both the dependent and the independent variables at constant and trend were not stationary at level. Thus, first difference operator was carried out before stationarity was attained. Thus, for all series, the null hypothesis of unit root test is rejected at 5 percent critical value. Given the results of IPS test, it is possible to apply panel co-integration method in order to test for the existence of the stable long-run relation among the variables.

Table 2: The Pedroni Panel Co-integration Test

\begin{tabular}{lccc}
\hline Test & Intercept+Trend & T-table & Prob. \\
\hline Panel $v$-Statistic & $12.23504^{* *}$ & I.686 & 0.0000 \\
Panel $r h o$-Statistic & $-2.107980^{* *}$ & $\mathrm{I} .686$ & 0.1907 \\
Panel $P P$-Statistic & $-1.933869^{* *}$ & $\mathrm{I} .686$ & 0.0728 \\
Panel ADF-Statistic & $-1.973020^{* *}$ & $\mathrm{I} .686$ & 0.2353 \\
Group $r h o$-Statistic & -0.481611 & $\mathrm{I} .686$ & 0.3150 \\
Group PP-Statistic: & -1.439432 & $\mathrm{I} .686$ & 0.0750 \\
Group ADF-Statistic & $-2.121670^{* *}$ & $\mathrm{I} .686$ & 0.0169 \\
\hline
\end{tabular}

Note: ** indicates rejection of the null hypothesis of no-co-integration at 5\%, levels of significance.

Sources: Researcher's Computation Based on E-view 10.

The result of the co-integration carried out for intercept and trend as presented in Table 2found that five which are 4panel statistics and 1 group panel statistics out of the 7-statistics reject null by hypothesis of no cointegration at the 5 percent level of significance for the panel-statistic and group-Statistic. However, since most of the statistics concluded in favour of cointegration, it is therefore concluded that, there is a long run cointegration among theoil (C) 2019, IJSMS 
rent, mineral rent and health status of citizens of Nigeria and Cameroon. Thus, governments of the two countries need to increase her yearly budget to the health sector so as to make the sector function well and hence reduction in mortality rate and outbreak of diseases as well as improve life expectancy.

\subsection{CONCLUSION}

The study examined comparative impact of oil rent on health status of Nigeria and Cameroon from 1995 to 2015. In other to achieve the objectives, annual time series data were collected on health (proxy by child mortality), oil rent and mineral rent and analyzed using the techniques of trend analysis, panel unit root test and panel co-integration test. The panel unit root and cointegration test showed that all the series are indeed stationary and have long run equilibrium relationship. The findings from the graphical analysis showed that oil rent improve the health status but not significantly. Meanwhile, mineral rent reduces child mortality but not in any way significantly. Comparatively, the graph showed that the rents from oil in Nigeria are lower than that of Cameroon. Cameroon performs better in rents from minerals than Nigeria. Also, Cameroon, capital expenditure on health has steadily been increasing since 1995 up to 2015while Nigeria seems not to take health expenditure serious hence the dismal performance in the infant mortality rates. Given the finding above, it recommended that revenue from oil should be towards inclusive growth, thereby impacting significantly on the health status and welfare of the citizens. Thus, there should be investment in primary as well as maternal health in the rural areas of mainly for the disadvantaged in society.

\section{REFERENCES}

[1] Agnihotri, G. (2015). How Much Does OPEC Really Earn? Retrieved on $12^{\text {th }}$ April, 2018 from www. oil price.com/Energy/EnergyGeneral/How-Much-Does-OPEC-Really-Earn.html

[2] Anyanwu, J.C. (2007). Health Expenditures and Health Outcomes in Africa.Economic Research Working Paper Series, No. 91, African Development Bank.

[3] Baldacci, E., Clements, B., Gupta, S., \& Cui, Q. (2008). Social Spending, Human Capita, Growth in Developing Countries. World Development, 36(8), 1317-1341.

[4] Boheman, H. \&Maxén, J. (2015). Oil Price Shocks Effect on Economic Growth - OPEC versus non-OPEC Economies. Lund University, School of Economics and Management.

[5] Boussalem, F., Boussalem, Z.\&Taiba, A. (2014). The Relationship between Public Spending on Health and Economic Growth in Algeria: Testing for Co-integration and Causality. International Journal of Business and Management, 2(3), 25-39.

[6] Ibrahim, A.J. \&Ohwofasa, O.B. (2015). Macroeconomic Determinants of Education Expenditure in Nigeria, 1980-2012. Developing Countries Studies, 5(6), 62-73

[7] Im, K.S., Pesaran, M.H.\& Shin, Y (2003). Testing for Unit Roots in Heterogeneous Panels. Journal of Econometrics 115, 53-74

[8] Opaleye, S.S., Okowa, W. \&Ohale, L. (2018). Oil Rent and Socioeconomic Outcomes in Selected oil Producing Countries in Africa. International Journal of Research in Business, Economic and Management, 2(2), 27-43

[9] Pedroni, P. (2001). Purchasing Power Parity Tests in Cointegrated Panels.Review of Economics and Statistics, 83(4), 727-731. ,

[10] Sachs, J. D. and Warner, A.M. (1997). Sources of Slow Growth in African Economies. Journal of African Economies, 6(3), 35 -76.

[11] Saleh, S.M. (2016). Oil and Macroeconomic Policies and Performance in Oman. A Doctoral Thesis submitted to Loughborough University Institutional Repository.

[12] Schultz, T.P. (2005). Productive Benefits of Health: Evidence from Low-Income Countries. Economic Growth Center Discussion Paper No. 903.

[13] WorldBank,2016.World DevelopmentReport.NewYork:OxfordUniversityPress World Health Organization. Annual Reports 2016. Washington. 